Saudi Journal of Economics and Finance

Abbreviated Key Title: Saudi J Econ Fin ISSN 2523-9414 (Print) | ISSN 2523-6563 (Online) Scholars Middle East Publishers, Dubai, United Arab Emirates Journal homepage: http://saudijournals.com/sjef/

Original Research Article

\title{
Development of Water Supply and Sanitation Community Based (Pamsimas) in District Teweh Baru
}

Irwanto*, Setia Budhi, Budi Suryadi

Master Program of Government Science, Lambung Mangkurat University, Banjarmasin, Indonesia

DOI: $10.36348 /$ sjef.2019.v03i11.009
*Corresponding author: Irwanto

\section{Abstract}

Program for Water Supply and Sanitation Community Based is a program of drinking water supply and sanitation based society. The program implemented by the Government of Indonesia with the support of the World Bank, this article aims to describe the implementation program in the District of New Teweh. So it can be seen how an increasing number of people to have access to drinking water and proper sanitation as well as practice clean and healthy living behavior. The descriptive method with the qualitative approach used in the study. The research instrument known as the "human instrument" theory is based on indicators of policy implementation by model Merilee S. Grindle. The indicator consists of policy content and context. Analysis of the data used in this study is an interactive analysis technique according to Miles and Huberman. Based on the results of research implementation Program for Water Supply and Sanitation in SubDistrict Community-Based New Teweh not optimal, lack of professionalism of the agencies involved in the implementation of this program, limited resources and program implementers lack of community participation in the development of the program and still less awareness about the importance of health and environmental hygiene

Keywords: Implementation, Provision of drinking water, sanitation.

Copyright @ 2019: This is an open-access article distributed under the terms of the Creative Commons Attribution license which permits unrestricted use, distribution, and reproduction in any medium for non-commercial use (NonCommercial, or CC-BY-NC) provided the original author and source are credited.

\section{PRELIMINARY}

The Indonesian government commits to achieve the Millennium Development Goals in the areas of water supply and sanitation (WSS-MDG), namely halve the proportion of people who do not have access to drinking water and basic sanitation by 2015. In line with that, the Government of Indonesia to implement programs drinking water Supply and sanitation community based (Pamsimas), which is a national program organized in a structured by the central government to local governments to improve access of rural people to the drinking water facilities and sanitation at the community-based approach. Pamsimas was started in 2008 through Pamsimas-I and to date, a total of 220 counties follow the Pamsimas-II program that had begun in 2013 .

PAMSIMAS-II program had ended in 2015 and has managed to increase access to safe drinking water and basic sanitation target more than 10,000 villages. To continue improving access to rural and suburban residents against drinking water and sanitation facilities to achieve MDG targets Pamsimas program resumed in 2016 to 2019 through Pamsimas-III with a target goal of 15,000 rural villages. Act No. 72004 Article 5 concerning water resources that the state guarantees the right of every person to obtain water for their minimum basic needs of daily life to meet the healthy, clean and productive. Pamsimas this is one program and the real action of central and local government with the support of the World Bank assistance, to improve the supply of drinking water, sanitation and improving public health is evenly distributed in Indonesia. The scope of activities PAMSIMAS Program; 1) The community empowerment and institutional development of local, 2) Improvement of health and hygiene behavior and sanitation services, 3) Provision of drinking water and general sanitation, 4) Incentives for rural/urban and district/city, and 5) Support implementation and project management.

Pamsimas is a drinking water supply program and community-based sanitation implemented by the Government of Indonesia with the support of the World Bank, the program is implemented in rural areas and suburbs. Access to safe drinking water and access to adequate sanitation are basic needs of society to achieve the standard of living, livelihood and productive. In efforts to achieve universal access to drinking water and sanitation by 2019, the Indonesian government has a strong commitment to achieving these targets by improving public health through the provision of 
facilities and infrastructure of water and sanitation. Based on these needs, The Indonesian government initiated the Water Development Program and Community Based Sanitation (Pamsimas III) which is a continuation of the previous PAMSIMAS program. Implementation, financing sources, comprehensive and integrative performed well from 8578 IBRD loan funds (International Bank for Reconstruction and Development), pure rupiah (APBN and APBD), as well as from APBDes and fund non-governmental contributions.

North Barito regency government support and are willing to implement Pamsimas Program. This was seen in the 2017 Barito regency government implement Pamsimas Program with the goal of 15 (fifteen) villages in seven (7) districts. New Teweh sub-district is one of the districts entrusted to implement this program with three objectives, namely the Village Malawaken village, Sikui village, and the village of Liang Naga. Implementation Program in the District Pamsimas New Teweh in three target villages are still some obstacles. One of them is the lack of direct involvement of the people in the village and less coordination Sikui Pamsimas manager. In this case, people are not directly involved in the development of Pamsimas for development carried out by builders and not the people in the village who build cooperation. And lack of coordination between the manager or organizer Pamsimas as from the Department of Human Settlements and health centers, as should the relevant agencies to socialize or triggered before the program was implemented. This article aims at the implementation of a program to provide clean water and sanitation. Thus there emerged a holistic discussion.

\section{RESEARCH METHODS}

Referring to the problem studied, the selection of a qualitative approach is the most suitable approach in the study. A qualitative approach and actual detail by looking at the problem and the purpose of the research that has been submitted previously. A qualitative approach as a research procedure that produces descriptive data in the form of words written or spoken of people and behaviors that can be observed [1]. This approach is directed at the individual background and holistic (whole). The descriptive method is chosen to look at the issues of research regarding the placement of water reservoirs PAMSIMAS Program uneven Sikui village and the village of Liang Naga. This is due to a lack of direct participation of the public against the Pamsimas Program in their village, and still a lack of public awareness about the importance of health and environmental hygiene. Research is located in North Barito district, Central Kalimantan Province precisely in the District of New Teweh involving two villages namely Sikui and Liang Naga Village. Determining the subject of research used the purposive technique [2]. The subject of research is the informants which can capture, understand, and meet the demands of researchers, have the ability reflective, nature, Take the time to interview. Here's a list of names of informants research:

Table-1: List of Researchers

\begin{tabular}{|c|l|l|l|}
\hline No. & \multicolumn{1}{|c|}{ name of informant } & \multicolumn{1}{|c|}{ Agency name } & office \\
\hline 1 & Yusri, and. kep & PHC Sikui & head of Puskesmas \\
\hline 2 & Hanz Hasannah, Amd. Keb & Pustu Liang Naga & head Pustu \\
\hline 3 & nano Murbono & Group self-reliance Rural communities Sikui & Board Pamsimas Village Sikui \\
\hline 4 & Karmilo & Group self-reliance Liang Naga village community & $\begin{array}{l}\text { Board PAMSIMAS village } \\
\text { dragon hold }\end{array}$ \\
\hline 5 & $\begin{array}{l}\text { a. Beni } \\
\text { b. Nurdin } \\
\text { c. Septiani } \\
\text { d. Yusup Apriadi } \\
\text { e. Suandi Dedi Jaya } \\
\text { f. Sri Rohadi } \\
\text { g. Hatlia } \\
\text { h. Dedi siswanto } \\
\text { i. Elda fitri }\end{array}$ & Residents in the village sikui & $\begin{array}{l}\text { Undertaking / Management } \\
\text { Pamsimas in the village each } \\
\text { each }\end{array}$ \\
\hline 6 & $\begin{array}{l}\text { a. Lamsiah } \\
\text { b. Juwandy } \\
\text { c. Maman }\end{array}$ & Residents in the village of Liang Naga & \\
\hline 7 & Darmansyah., SKM, MAP & Health Service North Barito & $\begin{array}{l}\text { The program targeted } \\
\text { communities in the village of } \\
\text { Liang Naga }\end{array}$ \\
\hline 8 & Noor Aini & Health Service North Barito & $\begin{array}{l}\text { Implementing Section } \\
\text { Environmental Health (PPL) }\end{array}$ \\
\hline 9 & Eri Saso & Bappeda kab. North Barito & $\begin{array}{l}\text { Staff Surveillance and Health } \\
\text { Environment }\end{array}$ \\
\hline 10 & Sekrening, S.ST & Department PUPR & $\begin{array}{l}\text { Physical Planning and } \\
\text { infrastructure Kasubid } \\
\text { BAPPEDA }\end{array}$ \\
\hline
\end{tabular}


Data collection techniques used by investigators to get the data needed in research. In the usual qualitative research data were collected by several data collection techniques, namely 1) interview, 2) observation, 3) documentation. Data collection techniques in this study using four techniques such as interviews, observation, documentation, the discussion focused where such techniques are expected to allow data and information required by researchers. Data analysis started since researchers conducting pre-field until the completion of the study, data analysis performed continuously without stopping until such data is saturated. Qualitative data analysis performed interactively and continues over time through so that the data is already saturated [3]. The size of the data saturation was marked by not obtaining further data or new information. Activities in the analysis including data collection, reduction, data presentation, and conclusion. While validation data in this study using triangulation. Triangulation is a technique that checks the data inspection data utilizing something other than the data $[4,1]$. The process of examining the data in this study conducted by measuring and comparing data from interviews with the observation of the data along with other compliance data [5].

\section{RESULTS AND DISCUSSION}

The government's policy of a country or a nation to development programs is a matter of great importance because it determines the progress of a country or nation. That is why only the development program can create the ability of state or the nation to attempt to establish a policy in the field of development in which result expected to enjoy all citizens of the country concerned. Based on the patterns of thought that have been put forward above, Still questionable activities related to development policy to benefit as much as possible in public life would also include management government and the development implementation itself [6].

Government policies relating to Policypublic reference to specific outcomes in a society where the formulation is through various stages. Public policy is a decision or a selection decision to take or not take the decision of existing problems in the community. Public policy is set either directly or indirectly manage natural resources, human resources, or management of the state order and the economy pointer rest public or general interest, namely the public at large, all layers of the population in a country. One of several government policies regarding the public interest is the Program for Water Supply and Sanitation (CommunitybasedPamsimas) [7, 8].

Pamsimas is a form of concrete action from the Indonesian government both central and local levels in an effort to rural development and improvement of drinking water supply and sanitation communities, and improving public health and the environment in the village, as well as working to reduce the number of diarrhea and other diseases that are transmitted through water and the environment clean. The scope of activities of Pamsimas:

1. Community Empowerment and Local Institutional Development.

2. Improvement of Health and Behavior Hygiene and Sanitation.

3. Provision of Water Supply and Sanitation.

4. Incentives for Village / Sub District / City; and

5. Support Implementation and Project Management.

Pamsimas is a program of drinking water supply, sanitation, and health. Pamsimas be effective and sustainable if the community based on the entire community involving both women and men, both rich and poor and is done through approaches that are responsive to community needs. The project responds to the needs of society and is expected to participate actively in society to prepare, implement, operationalize and maintain the facilities that have been built, as well as continuing to improve health status.

Pamsimas this is one of the programs of the Central Government in the construction that went into the villages to solve all the problems related to water and environment based society. This program comes of course with the initial goal is to help the people in the village in a variety of water needs for the activities of daily life and the health of their neighborhood. This program is not only for the village behind but to all the villages that do require a water supply or lack access to water in their village to improve the welfare of people in the village [6].

PAMSIMAS-II program had ended in 2015 and has managed to increase access to safe drinking water and basic sanitation target more than 10,000 villages. To continue improving access to rural and suburban residents against drinking water and sanitation facilities to achieve MDG targets Pamsimas Program continued in 216 to 2019 through Pamsimas-III with a target goal of 15,000 rural villages. Pamsimas achievement:

1. Their service sustainability of drinking water and sanitation.

2. The change of behavior towards healthy behavior and an increase in health care and sanitation.

3. Their priority to community programs for the poor and marginalized,

The benefits are expected with Pamsimas this is the growing number of people to access clean water or drinking water and proper sanitation as well as practicing good hygiene practices and healthy (hygiene), as part of efforts in achieving the MDGs target sectors of water and sanitation through 
mainstreaming and extension (scaling-up) a national community-based program.

Pamsimas structured and coordinated from the central level to the village level, at the institutional level in the center consists of Program Coordination Steering Committee, the Technical Team Program, and the Center for Project Management Unit (PMU). Program coordination is done through the Steering Committee and the Program Coordinating Technical Committee chaired by Bappenas Program and consists of departments and ministries concerned. Directorate General of Human Settlements as the executing agency formed a Central Project Management Unit (CPMU) to control the execution of the operational program.

As at the provincial level are the Provincial Coordination Team (TKP) formed by decree of the Governor chaired by Bappeda Province and consists of Dinas Cipta Karya Province, the Provincial Health Office and other agencies related to the need. For the district/city level each district/city has a team of District Coordination (CCPs) established by SK Regent / Mayor is chaired by the Head of Bappeda local, composed of the Department of Human Settlements and Public Health as well as the related agencies empowerment of communities and representatives of groups concerned / civil society / local NGOs.

Society as the main target in the manufacture of a policy by the government, which is for the welfare of the people of course interests are affected by the policies of this PAMSIMAS program is public. Where the recipient of the service of the community becomes the PAMSIMAS, and organizers or organizers in Pamsimas Program. Since the objective of this PAMSIMAS program is to improve access to drinking water and sanitation for the people, both in rural communities that have a shortage of clean water coverage and drinking water as well as poor people especially in underdeveloped areas.

Pamsimas course the benefits are very good, very useful and help the community in carrying out their daily activities, because as we know that a man would need water in our daily life, whether for drinking, washing, bathing and so on. So with this Pamsimas Program, people who initially had difficulty meeting their water needs, or people who usually perform such activities outdoors in the garden or on the river, now with this Pamsimas people can do in their homes.

Pamsimas program aims to change the habits of people to live a clean and healthy. The program creates a feeling of concern for hygiene and the environment they live in. Therefore, it can affect the cleanliness and health of their respective communities themselves. Due to community activities for their daily activities by the river or in the garden, of course, people do not keep a clean environment. Then it can lead to environmental contamination and spreading or making the environment dirty and cause the emergence of diseases that can be transmitted from the water and the environment such for example diarrhea.

Type of benefits expected with Pamsimas this is the growing number of people to access clean water or drinking water and proper sanitation as well as practicing good hygiene practices and healthy (hygiene), as part of efforts in achieving the MDGs target sectors of water and sanitation through mainstreaming and extension (scaling-up) a national community-based program. The degree of change to be achieved or the achievement of the PAMSIMAS Program course is to fulfill the community needs clean water and drinking water and the implementation of community-based sanitation. Then the change in people's behavior that stops Babs and CTPS and increased public awareness about the importance of clean and healthy living.

Coordination is done in this Pamsimas Program is the coordination of Bappeda-Department of Health- Department of Human Settlements and-district health centers related to the working area viewed from the recipients of his sector in the region. Pamsimas in the implementation of structured and coordinated from the central level to the village level. At the institutional level in the center consists of the Program Coordination Steering Committee, the Technical Team Program, and the Center for Project Management Unit (PMU). Program coordination is done through the Steering Committee and the Program Coordinating Technical Committee chaired by Bappenas Program and consists of departments and ministries concerned. Directorate General of Human Settlements as the executing agency formed a Central Project Management Unit (CPMU) to control the execution of the operational program.

District / City each District / City have Tim District Coordination (TKK) is formed by SK Regent / Mayor is chaired by the Head of Bappeda local, composed of the Department of Human Settlements and Public Health as well as the related agencies empowerment of communities and representatives of groups concerned / civil society / local NGOs, Human resources are deployed at institutional level in the center consists of Program Coordination Steering Committee, the Technical Team Program, and the Center for Project Management Unit (PMU). Program coordination is done through the Steering Committee and the Program Coordinating Technical Committee chaired by Bappenas Program and consists of departments and ministries concerned. Directorate General of Human Settlements as the executing agency formed a Central Project Management Unit (CPMU) to control the execution of the operational program. 
There are provincial-level Provincial Coordination Team (TKP) formed by decree of the Governor chaired by Bappeda Province and consists of Dinas Cipta Karya Province, the Provincial Health Office and other agencies related to the need. District/City each District / City have Tim District Coordination (CCPs) established by SK Regent / Mayor is chaired by the Head of Bappeda local, composed of the Department of Human Settlements and Public Health as well as the related agencies empowerment of communities and representatives of groups concerned / civil society / NGOs local.

Set a drinking water catchment point and clean water in both rural and rural Sikui Liang Naga, in the implementation is not based following the needs and the level of compliance. Where power, interests, and strategies of the actors into abuses committed by the actors involved, so slow and less than optimal program implementation.

The designation of the reservoir is, of course, led to irrigation or distribution of drinking water and clean water is not evenly distributed in every community in the village, either in the village or in the village Liang Sikui Naga. As has been noted by Ms. Uswatun Hasanah, Amd. Keb above, in the village of Liang Naga until there are people who threaten a machete which forced construction is done near his home for personal use. It is certainly not following the existing regulations and there is a lack of professionalism and the intervention of the actor involved or ruler like because of relatives, family, and so on which can be above selfish interests above the common interests or public interests.

In the village of Liang Naga on placement, there is one point that is placed around the home page of the village head, which caused some residents, are reluctant or feel awkward to ask for water or to use such access to their daily activities. Due to its commencement uneven with the intervention of power, interests, and the strategy of the actors directly involved and are not directly involved in the implementation or distribution of water to the citizens is not running optimally [9].

Institutional level in the center consists of the Program Coordination Steering Committee, the Technical Team Program, and the Center for Project Management Unit (PMU). Program coordination is done through the Steering Committee and the Program Coordinating Technical Committee chaired by Bappenas Program and consists of departments and ministries concerned. Directorate General of Human Settlements as the executing agency formed a Central Project Management Unit (CPMU) to control the execution of the operational program. As at the provincial level are the Provincial Coordination Team (TKP) formed by decree of the Governor chaired by
Bappeda Province and consists of Dinas Cipta Karya Province, the Provincial Health Office and other agencies related to the need. District/city level.

All the good start of the implementor executing or implementing the central level to the village level have their respective roles in carrying out and implementing the program [10]. Central level institutions such as the Directorate General of Public Works, Ministry of Health, Ministry of Interior, and the Ministry of National Education. As for the provincial level are the Provincial Coordination Team (TKP) which was established by decree of the Governor chaired by the Head of Provincial Bappeda, with members Provincial Department of Human Settlements Division, Department / Agency / Agency for Community Empowerment Province, the Provincial Health Office and related agencies as needed.

District/city level local chaired by Head of Planning Agency, and consists of the Department of Human Settlements, Department of Provincial Human Settlements Division, Department / Agency / Community Empowerment Agency Provincial Health Office and related agencies empowerment and representatives of civil society groups / local NGOs. Coordination is a very important aspect in the success of this Pamsimas Program, which is more important is to be on the district level as it relates to the distribution and geography of the village / sub-target in the region because the District is very appropriate for the target group coordinating Pamsimas Program.

\section{CONCLUSION}

Implementation carried out cannot be said to be successful and run optimally, there is storage of clean water reservoirs of programs that are not evenly distributed in the placement, then the lack of participation of the community in the success of this government program, the lack of coordination departments or agencies, and the lack of running instructions or technical reference on Pamsimas Program. Factors that become an obstacle to the successful implementation of Program Pamsimas are less professionalism than the official or officials concerned in this program, then the posting of the water reservoir is less a strategy for the placement still involves the role or powers of the actors involved to decide the storage location the clean water reservoirs, lack of executive power source also factored into less optimal implementation of the program. Then less participation of people in the development and still less awareness about the importance of health and environmental hygiene. Continuation of Program PAMSIMAS its shelter-even less sustainable and less manicured cause lack of optimal implementation Pamsimas. 


\section{REFERENCES}

1. Moleong, L. J. (2004). Metodologi Penelitian Kualitatif. Bandung: Remaja. Rosdakarya.

2. Satori, D. (2011). Metode Penelitian Kualitatif. Bandung: Alfabeta.

3. Huberman, A., \& Miles, M. B. (1992). Analisis data kualitatif Terj. Tjetjep Rohidi. Jakarta: UI Press.

4. Nasution. (2003). Metode Penelitian Naturalistik Kualitatif. Bandung: Tarsito.

5. Mulyana, D. (2001). Metodologi Penelitian Kualitatif: Paradigma Baru Ilmu Komunikasi dan
Ilmu Sosial Lainnya. Bandung: PT Remaja Rosdakarya.

6. Beratha, N. (1982). Desa, Publik, Konsep, Teori dan Aplikasi. Yogyakarta: Pustaka Pelajar.

7. Mahsun, M. (2006). Pengukuran Kinerja Sektor Publik. Yogyakarta: Penerbit BPFE.

8. Subarsono. (2005). Analisis Kebijakan Publik, Konsep, Teori dan Aplikasi. Yogyakarta: Penerbit Pustaka Belajar.

9. Mulyadi, D. (2016). Studi Kebijakan Publik dan Pelayanan Publik. Bandung: Alfabeta.

10. Winarno, B. (2002). Teori dan Proses Kebijakan Publik. Yogyakarta: Media Pressindo. 